\title{
Chapter 8 \\ Institutional Culture of Mergers \\ and Alliances in South Africa
}

\author{
Martin Hall
}

\subsection{Introduction}

South Africa's extensive set of higher education mergers were implemented between 2002 and 2005. While there has not been a systematic evaluation of this merger process, that created 11 new institutions from 26 merger partners and affected $62 \%$ of the South African higher education system (in terms of current student registrations), a full set of independent and rigorous quality assurance reports provide the basis for evaluating the consequences of the policy. These institutional audits suggest three broad types of outcome: mergers that have resulted in well functioning new institutions, failed mergers, and a set of new universities that are still responding to the consequences of merger. Finally, the publication of South Africa's new National Development Plan in 2012 and a new analysis of student access and success across the country's public higher education system as a whole, completed in 2013, allow an assessment of the degree to which the objectives of the 2002 merger plan have been achieved.

South African society is shaped by three centuries of racial segregation. This was formalized as apartheid in 1948 when the National Party assumed power. The first democratic elections were held in 1994, and 2 years later a new constitution embedded a Bill of Rights that included the principle of equal access to education, and the imperative of redress for the consequence of previous unfair discrimination. Translating these formal rights into substantive opportunities has required the comprehensive reconstruction of a wide range of organizations, including the country's Higher Education institutions. The newly-elected government had inherited an education system shaped by segregation in terms of race, ethnicity

\footnotetext{
M. Hall $(\bowtie)$

Vice-Chancellor, University of Salford, Lancashire, UK

Graduate School of Business, University of Cape Town, Cape Town, South Africa

e-mail: martin.hall@salford.ac.uk
} 
and language; a bewildering array that ranged from the conventional to the barely functional. Following an extensive series of commissions, reports and inquiries, the Minister for Education announced in 2002 an extensive and mandatory process of mergers (Hall et al. 2004a).

As part of this merger process, the Council on Higher Education (a statutory body charged with advising the Minister) commissioned a study on the governance of mergers. This work, which was later published, provided a window on the merger process at a key stage of planning and implementation (see Hall et al. 2004a; also Hall et al. 2002, 2004b; Hall and Symes 2003, 2005).

The chapter that follows here provides an overview of the discourse of the merger process in late 2002 and early 2003, and perceptions of these mergers over the decade that has followed. This is neither a comprehensive report on South Africa's Higher Education reconstruction or a systematic analysis of the consequences. It does, however, point to some key outcomes of this unique experiment in restructuring a university system at the national level by means of a mandated set of processes, rather than through voluntary arrangements.

The extent to which South Africa's 2002 merger plan has succeeded after the first decade can be assessed by asking three sets of questions. Firstly, and at the systemic level, has the reorganization of the national higher education system broken the "structural embrace" of apartheid architecture? Has the merger process contributed to addressing South Africa's overall labour force requirements? Second, at the level of the individual institution, which sets of conditions that were discernable at the beginning of the merger process in 2002 appear to have driven degrees of success over the following decade? How have the new types of institution envisaged in 2002 fared over the following decade? Third, from the perspective of students and their interests, to what extent has the merger process contributed to addressing access to Higher Education and subsequent levels of graduations? To what extent are South African universities open on merit, irrespective of race or socioeconomic class?

As Njabulo Ndebele, previously Vice-Chancellor of two very different South African universities, put it in the introduction to the key review of South African Higher Education that was released in 2013:

In moments of great historic transitions the world over, extremes of action are normal. Corrective in their intent, they are part of the logic of change. The ascendant power requires 'its own people' in large numbers to replace those that had kept going the passing old order. Statistics and quantification of the progress of change carry political import. They can validate or invalidate the new political order. Because they become part of the definition of success or failure, they bear consequences. Woe unto the new order that does not pay attention to them (Council on Higher Education 2013a).

\subsection{Context}

The merger plan that was approved by the South African government in 2002 has to be understood in the context of both the long years of formal segregation and of the broader policy imperatives that faced the newly-elected administration from 1994 onwards. 
Apartheid legislation and practice had resulted in a unique combination of Higher Education governance arrangements, ranging from institutional autonomy in the British tradition for universities intended as reserved for white students (for example, the University of Cape Town, the University of the Witwatersrand), to direct government control in what were in effect extensions of a segregated civil service (for example, the University of Bophuthatswana, later renamed the University of the North-West, and the University of Transkei). Complicating things further was a binary division between vocational provision (technikons) and a bilateral distinction between Afrikaans medium institutions (such as the University of Pretoria and Technikon Port Elizabeth) and English medium provision (for example, Rhodes University and Cape Technikon).

Spatial segregation had been a formative aspect of South Africa's history for well over a century, enforced through legislation such as the Natives Land Act of 1913 and the Group Areas Act of 1950. Not surprisingly, spatial segregation had left a definitive imprint on the higher education system. By the end of the apartheid era there were three, racially-defined education administrations (for Whites, Coloureds and Indians) and multiple, ethnically-defined "homeland" administrations for Africans, the origins of universities such as Bophuthatswana, Venda and Zululand.

Whether institutions had a history of legal autonomy or of direct control, the State carried a substantial burden through funding a significant proportion of teaching and research costs and, increasingly after 1994, of providing student funding support through the National Student Financial Aid Scheme (NSFAS). Not surprisingly, there was a prevalent assumption that the country's entire Higher Education system was unfit for purpose for a post-apartheid South Africa (National Commission on Higher Education 1996).

There had been a long tradition of critique and active opposition to this segregated and discriminatory system. The eventual shape of a normalized Higher Education policy began to take form through the National Education Policy Investigation and its wide-ranging sets of reports (NEPI 1993) and the work of the National Commission on Higher Education between 1995 and 1996 (National Commission on Higher Education 1996). This led in turn to the key 1997 White Paper, which set out the principles for an open, non-discriminatory Higher Education system and which remains a key benchmark today (South African Government 1997a).

Following reports by the Council on Higher Education (a statutory body) and a National Commission on Higher Education, the government announced in 2002 a comprehensive set of compulsory mergers that would restructure South Africa's Higher Education system and reduce the apartheid legacy of 36 universities, technikons and institutes to 23 universities within the following 3 years (Council on Higher Education 2000, 2002; Hall et al. 2002; South African Government 2001, 2002a). This is summarized in Table 8.1.

The outcome of the merger process was three types of institutions: "traditional" universities, universities of technology (previously technikons, offering vocationally-oriented qualifications) and "comprehensive" universities (intended 
Table 8.1 The restructuring of South African higher education

\begin{tabular}{|c|c|c|c|}
\hline & Traditional universities & & \\
\hline 24,772 & University of Cape Town & Unchanged & \\
\hline 10741 & University of Fort Hare & $\begin{array}{l}\text { Amalgamated with part of } \\
\text { Rhodes University }\end{array}$ & \\
\hline 29,901 & University of the Free State & Unchanged & \\
\hline \multirow[t]{2}{*}{41,224} & \multirow[t]{2}{*}{ University of KwaZulu-Natal } & University of Natal & \multirow[t]{2}{*}{ January 2004} \\
\hline & & University of Durban-Westville & \\
\hline \multirow[t]{2}{*}{18,205} & \multirow[t]{2}{*}{ University of Limpopo } & University of the North & \multirow[t]{2}{*}{ January 2005} \\
\hline & & $\begin{array}{l}\text { Medical University of } \\
\text { South Africa }\end{array}$ & \\
\hline \multirow[t]{2}{*}{55,732} & \multirow[t]{2}{*}{ North-West University } & $\begin{array}{l}\text { Potchefstroom University for } \\
\text { Christian Higher Education }\end{array}$ & \multirow[t]{2}{*}{ January 2004} \\
\hline & & University of the North-West & \\
\hline 57,114 & University of Pretoria & Unchanged & \\
\hline 7,169 & Rhodes University & Campus surrendered to Fort Hare & \\
\hline 27,344 & University of Stellenbosch & Unchanged & \\
\hline 18,059 & University of the Western Cape & Unchanged & \\
\hline \multirow[t]{2}{*}{29,498} & University of the Witwatersrand & Unchanged & \\
\hline & Comprehensive Universities & & \\
\hline \multirow[t]{3}{*}{48,315} & \multirow[t]{3}{*}{ University of Johannesburg } & Rand Afrikaans University & \multirow[t]{3}{*}{ January 2005} \\
\hline & & $\begin{array}{l}\text { Vista University Distance Edu- } \\
\text { cation campus }\end{array}$ & \\
\hline & & Technikon Witwatersrand & \\
\hline \multirow[t]{2}{*}{26,119} & \multirow{2}{*}{$\begin{array}{l}\text { Nelson Mandela Metropolitan } \\
\text { University }\end{array}$} & University of Port Elizabeth & \multirow[t]{2}{*}{ January 2005} \\
\hline & & Technikon Port Elizabeth & \\
\hline \multirow[t]{3}{*}{293,437} & \multirow[t]{3}{*}{ University of South Africa } & University of South Africa & \multirow[t]{3}{*}{ January 2004} \\
\hline & & Technikon SA & \\
\hline & & $\begin{array}{l}\text { Vista University Distance Edu- } \\
\text { cation campus }\end{array}$ & \\
\hline 10,679 & University of Venda & Unchanged & \\
\hline \multirow[t]{3}{*}{26,734} & \multirow{3}{*}{$\begin{array}{l}\text { Walter Sisulu University of } \\
\text { Technology and Science }\end{array}$} & University of Transkei & \multirow[t]{3}{*}{ January 2005} \\
\hline & & Border Technikon & \\
\hline & & Eastern Cape Technikon & \\
\hline \multirow[t]{2}{*}{14,725} & University of Zululand & Unchanged & \\
\hline & Universities of Technology & & \\
\hline \multirow[t]{2}{*}{32,167} & \multirow{2}{*}{$\begin{array}{l}\text { Cape Peninsula University of } \\
\text { Technology }\end{array}$} & Peninsula Technikon & \multirow[t]{2}{*}{ January 2005} \\
\hline & & Cape Technikon & \\
\hline 12,583 & $\begin{array}{l}\text { Central University of } \\
\text { Technology }\end{array}$ & Unchanged & \\
\hline \multirow[t]{2}{*}{25,184} & \multirow{2}{*}{$\begin{array}{l}\text { Durban University of } \\
\text { Technology }\end{array}$} & ML Sultan Technikon & \multirow[t]{2}{*}{2002} \\
\hline & & Natal Technikon & \\
\hline 10,003 & $\begin{array}{l}\text { Mangosuthu University of } \\
\text { Technology }\end{array}$ & Unchanged & \\
\hline
\end{tabular}


Table 8.1 (continued)

\begin{tabular}{l|l|l|l}
\hline & Traditional universities & & \\
\hline 51,785 & $\begin{array}{l}\text { Tshwane University of } \\
\text { Technology }\end{array}$ & Pretoria Technikon & January 2004 \\
\cline { 3 - 3 } & Technikon Northern Gauteng & \\
\cline { 3 - 3 } 21,416 & North-West Technikon & \\
\hline 982,936 & $\begin{array}{l}\text { Vaal University of Technology } \\
\text { Totandergraduate student }\end{array}$ & Unchanged & \\
\hline
\end{tabular}

to offer a combination of academic and vocational qualifications). Twelve institutions would emerge largely untouched by the merger process, despite the earlier conclusion of the National Commission on Higher Education that no existing institution was fit for purpose. One merger had almost been completed voluntarily at the time that the government approved the overall policy, and the remaining ten would originate in a merger process in two phases, to be completed by January 2004 and January 2005 (South African Government 2002b).

It was in this context that the Council on Higher Education decided to commission additional research into the governance implications of institutional mergers and incorporations - the basis for the perspective presented here. In late 2002 and through the first half of 2003, nine institutions were visited, documentation collected and interviews with leadership and senior management conducted. The sample covered the full range of existing institutions, both by type and geographical location. The report was completed in June 2003 and published in August 2004 (Hall et al. 2004b).

At the time of this research, only one merger had been completed (between the M. L. Sultan and Natal Technikons, combined as the Durban Institute of Technology in April 2002, later renamed the Durban University of Technology). Those at the institutions visited who had been in intense discussions about mergers and merger processes for more than a year, knew their own broad trajectories, with projected mergers either the following year or 18 months into the future. But many aspects of process, resourcing and other details were unclear or unknown. Given this, a primary value of this work was as a record of the uncertainties and ambiguities that are inevitable in the gap between the development and implementation of system-level policies, and the pragmatics and consequences of implementation at the institutional level. The decisions and accommodations made in this "gap" have had a significant influence on the institutional forms that were to emerge, and which shape South Africa's Higher Education today.

\subsection{Responses from the Front Line}

A merger process can usefully be understood as having three phases: a pre-merger phase, a transitional or interim phase, and a post-merger integration phase (following Goedegebuure 1992; Eastman and Lang 2001). In the requirements set out in 
South Africa's Higher Education Act, the pre-merger phase begins when the Minister gives written notice of the intention to merge two or more institutions, and opens a 90-day period for representations to be made. Following this, the Minister gives official notice that the merger will proceed, initiating the transitional phase of the process (South African Government 1997b). Institutional visits and interviews all took place in this transitional phase. During this time, which lasts between 6 months and a year, the Minister appoints an Interim Council which, in turn, appoints interim management. The post-merger phase begins when the Interim Council surrenders authority to the incoming Council of the newly formed university.

Despite the specifications of the Higher Education Act, there were ambiguities in interpretation and omissions of detail (Hall et al. 2004a). The voluntary merger of M. L. Sultan and Natal Technikons had proved difficult, with legal challenges, industrial disputes and considerable negative publicity (Chetty 2010). In the long period of uncertainty prior to the conclusion of the formal period of pre-merger representations in December 2002, there had been a considerable degree of political positioning by the affected institutions. For example, the geographically adjacent University of the Western Cape and the Peninsula Technikon had objected to the suggestion that they should merge to form a "comprehensive university"; the University of the Western Cape was exempted from merger while the Peninsula Technikon was merged with the Cape Technikon despite objections, forming a new "university of technology" with widely separate campuses. There had also been an abrasive, public, dispute between the Minister and the leadership of the University of South Africa, a distance education provider that objected to being merged with other elements of South Africa's distance provision (Hall et al. 2004a).

By early 2003, when the interviews were conducted, there was a general acceptance that mergers would go ahead, considerable confusion about what to expect, and realism about the need to take advantage of any opportunity to achieve the best possible outcome. At the beginning of the year, the Ministry of Education had written to all institutions affected by the merger process requiring, by June 2003 , notification of the name, physical location and proposed start date for the newly-formed university, details of the process that would be followed to comply with labour legislation, and nominations for membership of the Interim Council (Hall et al. 2004a).

Given that there were no precedents, and scant guidelines, as to how these key decisions were to be made ahead of the installations of the new Interim Councils, pragmatism was the order of the day. Most institutions had set up internal merger processes and joint merger committees with their mandated partners. Merger committees were usually supported by task teams and merger managers, looking ahead to the requirements that would be faced by joint merger committees and Interim Councils as the transitional phase gathered momentum. Task teams were charged with specific areas such as academic administration, human resources, student services, information technology and buildings and infrastructure. Merger managers, often senior administrators or senior academics on secondment, always 
worked closely with the Vice-Chancellor or Rector. Their primary responsibilities were coordination, change management and communication (Hall et al. 2004a).

Not surprisingly, there was at this time an overwhelming concern with practicalities, both because of the enormity of the merger challenge and because, throughout the merger processes, institutions were expected to continue to offer their full suites of academic programmes to their currently registered students, and to recruit new cohorts of students for the academic year that would begin in early 2004. In particular, there were significant anxieties about the financing of the merger process and the extent of the capacity for change. National budget provision was seen as too little and too late. Independent estimates had put the sectoral costs of the merger exercise at between ZAR4.8bn and ZAR5.7bn ( $\$ 600 \mathrm{~m}$ to $\$ 710 \mathrm{~m}$ at the prevailing rate of exchange). In December 2002, the government was reported to have set aside ZAR3.1bn ( $\$ 380 \mathrm{~m})$, and the national budget for 2003 allocated only ZAR $800 \mathrm{~m}(\$ 100 \mathrm{~m})$ for each of the following 3 years (Hall et al. 2004a).

A further concern was compliance with labour legislation. Despite the fact that COSATU, South Africa's federation of trade unions, was formally part of the ANC government and committed to the restructuring of apartheid-era institutions, there had been significant challenges to the voluntary merger between M. L. Sultan and Natal Technikons by trade unions, resulting in court action. In many cases, university and technikon campuses were among the largest local employers and any efficiency process that removed jobs would have a significant impact on local economies and livelihoods. In a reflection of the government's political sensitivity to labour-related issues, the Higher Education Act had been amended in 2002 to require that all contracts of employment be transferred automatically to the merged institution, while at the same time allowing that pre-merger rationalization could take place in the terms of the existing Labour Relations Act (South African Government 2002b). Merging institutions were left to navigate the evident complexity of this legal framework.

Taken together, Councils, institutional leaders, merger committees and merger managers were faced with the formidable task of completing a broad set of due diligence requirements ahead of passing the baton to incoming Interim Councils and interim managers for the newly formed universities. They were expected to identify, audit, verify and disclose the assets, liabilities and obligations, systems and controls of the merging institutions, as well as deal with political complexities that ranged from labour relations to the often deeply-felt question of the name by which the new university would be known. In some cases - and as a consequence of the geographical segregation that had been a distinctive feature of apartheid - these processes had to be managed across campuses that were widely distributed. Some were spread across metropolitan regions (Johannesburg, Durban and Cape Town) or, in some cases, were hundreds of kilometres apart (for example, the merging University of the North-West and Potchefstroom University for Christian Higher Education).

Looming behind these immediate concerns - and the Minister's requirements for a set of specific outcomes by mid-2003 - was substantial unease about the educational mission (and therefore the academic viability) of the 11 new universities that 
would emerge from the merger process. All who were interviewed believed that due diligence should extend to key issues in academic and institutional planning, including academic programme and course structures (and duplication of courses across institutions), qualification levels of staff, equity profiles of staff and students, student throughput rates and student fee levels. But the practical ability to do this varied greatly according to the magnitude of specific circumstances and resource capacity.

In addition, in restructuring the Higher Education system as a whole, the state had created a new type of institution, the "comprehensive university". While this was evidently intended to serve where a former technikon was to merge with a previous university (four of the new comprehensive universities would have this heritage), two unchanged institutions were also now designated as comprehensive universities (the Universities of Venda and of Zululand). At the headline level it was apparent that comprehensive universities were to offer both vocational and academic qualifications, seeking to achieve appropriate overall balance in the range of qualifications attained and avoiding "mission drift", whereby higher-status degree programmes were favoured at the expense of the mix of vocational qualifications required for overall economic development. However, there were no established principles or guidelines for how curricula should be structured or qualification frameworks implemented. Given that the state had the direct authority to steer the higher education system as a whole, in authorizing or withholding the recognition of qualifications and institutional funding through teaching grants, there were evident implications for the future viability of universities in this new category. However, given contingent demands, short time scales and resource constraints, there was often little that institutional leaders could do to address these issues (Hall et al. 2004a).

All those interviewed believed that integrating the academic functions of the newly-formed universities - whatever their type - would be a long and difficult process. Firstly, it would not be possible to introduce a new set of academic programmes for the launch date of the new university (at the beginning of either the 2004 or 2005 academic years). In addition, "pipeline" students already enrolled would have to be taught through to the completion of their curricula; given the low throughput levels for South African Higher Education, this could only be completed 4 years after merger, at the earliest (in 2008 or 2009). During this period of transition, it would in some cases be necessary to offer two sets of academic programmes at the same time, but without additional resources. Further, and as in all universities, changes to the profiles of academic programmes on offer would require extensive changes in administrative and professional staffing, in the composition and qualification levels of academic staff and in physical resources (Hall et al. 2004a).

Despite these concerns, in all cases the transitional phase of the merger process was completed and the newly-merged universities were launched, as planned, at the beginning of either the 2004 or the 2005 academic years. 


\subsection{Post-merger: A Decade of Integration}

Despite the evident complexity of South Africa's project for Higher Education restructuring - and its high political, social and economic stakes - there has been no formal, comprehensive review of its outcomes. However, the audit reports carried out under the auspices of the Higher Education Quality Committee provide a considered set of perspectives on the outcomes of the merger process (Council on Higher Education 2013b). These have been completed for all but one of the new universities created by mergers, and have been conducted to a rigorous and comprehensive standard by panels of independent reviewers. While the HEQC's primary remit is the quality of teaching and research, all the audit reports also provide the viewpoint of the panel on the outcomes of merger. These reports are complemented by the narrower remit of the Higher Education Merger Study Group, which has been independently funded to provide continuity between the 2001 National Working Group and the outcomes of its recommendations (Gillard et al. 2012). Taken together, these reports provide the basis for a rough, threefold typology of institutional circumstances over the years, that followed the implementation of mergers.

Firstly, HEQC audit reports see four mergers as broadly successful: Nelson Mandela Metropolitan University, the University of Johannesburg, North-West University and the University of KwaZulu-Natal.

The HEQC's audit of Nelson Mandela Metropolitan University was carried out in 2008 and commended "the speed and effectiveness" of implementing operational measures, management structures and stable governance, while also noting some degree of staff demoralization that had damaged the quality of teaching (Council on Higher Education 2009a). The Higher Education Merger Study Group agreed with this assessment, noting that the new university "moved quickly to draw large numbers of people into developing policies and structures" and that "when staff of merged academic departments worked together, the department often benefited". Nevertheless, "different academic requirements and cultures [...] were often intensified when they remained on separate sites [...]". Incomplete issues included remuneration anomalies and the "academic shape" of the new university, particularly the future of vocational and diploma programmes (Gillard et al. 2012. See also Van Straaten Theron and Dodd 2011).

The HEQC visited the University of Johannesburg in the following year, where a different audit panel found that there had been "a radical organizational redesign and renewal process" that had included "considerable financial and human resources investment directed at amplifying (the university's) teaching and learning capacity" as well as "movement towards equalising infrastructure across campuses". As a result, "the institution appears considerably settled in relation to the operational aspects of the merger and is now in a position to embark on the task of giving expression to its mission and vision". Most staff members interviewed told the HEQC panel that the merger had been successful in producing a new institutional identity, although "in general, academic staff members still think in terms of 
the old technikon and university divide, especially with regard to programme offerings" (Council on Higher Education 2010a).

The Higher Education Merger Study Group's report for the University of Johannesburg adds more detail to the HEQC panel's comments. "Perhaps the biggest challenge", the Study Group concluded, was "the coexistence of degrees and ex-technikon diplomas in the same institution" (Gillard et al. 2012; see also Goldman 2012).

North-West University was also audited by the HEQC in 2009. Here, the panel made particular note of the challenge in bringing together three campuses across two provinces, separated from one another by a distance of at least $200 \mathrm{~km}$. Given this, the audit panel commended the notable progress made across a wide range of merger requirements, but also noted "issues of student and staff profile, institutional culture and programme alignment" and that "the vast disparities between the campuses, for instance in infrastructure, resources and staffing, continue to exist". The merger could not be regarded as complete until "students receive comparable levels and quality of programmes on all three campuses" (Council on Higher Education 2010b).

Evaluating progress at the new University of KwaZulu-Natal is complicated by the Council on Higher Education's decision not to publish the HEQC's report from the 2008 audit. ${ }^{1}$ This deficit is, in part, mediated by the work of the Higher Education Merger Study Group. This report notes that there had been "daunting challenges" facing the merging institutions, and that the new university had over 40,000 students and over 4,000 staff, with several large campuses. A four-College model had been adopted to give the 56 academic schools coherence, but "disadvantages also surfaced": "decision-making was often duplicated, because of the additional layer between faculties and Senate. The spread of activities over so many campuses inevitably prevented easy contact between people". At the Study Group's last visit to the university, in 2007, a range of staffing issues was unresolved, and consolidation of academic programmes was incomplete: "some academic areas had taken the opportunity to revamp curricula. Others, whether because of various complications or active or covert resistance, had been less successful" (Gillard et al. 2012).

While the unpublished HEQC audit report cannot be cited, long-standing tensions, that have characterized the new university since its inception, are a matter of public record and have centred on disciplinary action taken against two members of the University Senate after they tabled a critical report (McKune 2009). Nevertheless, it is apparent that the new University of KwaZulu-Natal has been successful in

\footnotetext{
${ }^{1}$ I was the Chair of the HEQC audit panel for the University of KwaZulu-Natal in 2008, and endorsed the report that the HEQC submitted to the Council on Higher Education. The audit was abandoned by the Council when confidential correspondence concerning the conduct of the University's leadership was made public, and following the intervention in the audit process by the Vice-Chancellor. The audit report, while completed and endorsed by the audit panel, has yet to be released by the CHE. See Brooks (2011) for an account of this affair.
} 
implementing its formative merger and through the following phase of consolidation.

These four, favourably reviewed, institutions have a number of features in common. Each has included a "historically advantaged" institution previously of university status (the University of Port Elizabeth, Rand Afrikaans University, Potchefstroom University for Christian Higher Education and the University of Natal). Each was able to move quickly and effectively to integrate, as far as was possible, a new organizational and operational structure. All, though, still faced considerable challenges in bringing the full range of their newly-combined staff with them in identifying with the new institution and its mission and purpose, and in integrating and aligning academic programmes across the new institution.

Secondly, and in striking contrast, are HEQC reports on two problematic merger outcomes: the University of Limpopo and the Walter Sisulu University of Technology and Science.

The HEQC audit of the Walter Sisulu University of Technology and Science was delayed by problems at the institution, finally taking place in 2011 . The panel found that there were widely divergent views on the mission and purpose of the university. Their report described the merger as "a difficult and painful process, with significant resistance to the merger by staff, significant under-resourcing, weak financial management, and on-going fragmentation and lack of institutional coherence across campuses". Poor management of the merger process had adversely affected staff morale. There were "many outstanding matters which must be resolved urgently, including the finalisation of the organisational structure, harmonisation of processes and systems, development of plans for financial sustainability, regularisation of staff contracts and job descriptions to ensure equitable service conditions, and implementation of a performance management system". Unless these issues were addressed immediately, the panel reported, "the success of WSU, including educational quality and its sustainability as a higher education institution will be put at high risk" (Council on Higher Education 2011b).

Indeed, the Minister immediately appointed an Independent Assessor who reported in graphic detail: "an institution in crisis, riddled with conflict, mistrust and disaffection among its stakeholders. There is complete loss of confidence in university leadership [...] There are constant conflicts and battles between employees and management, as well as between students and management, incurring frequent strikes by workers and class boycotts by students. Labour unrest has included 'Staff hostage taking, victimization of students, eviction of staff from offices and lecture rooms, locking out of staff, seizing of university keys and locking up of university buildings, abandoning of work stations by staff, closing and barricading of access entrances to the institution' [...] Student uprisings have included arson (the torching of university buses) and other acts of violence. There is a pervasive disregard for rules and authority, and an air of anarchy rules within the institution" (South African Government 2011c). Following this report, the Council and Vice-Chancellor were suspended by the Minister, who in October 2011 used his authority in terms of the Higher Education Act to place the university under the control of an Administrator, reporting directly to him. 
The HEQC audit of the University of Limpopo had been completed in 2010, and also described comprehensive failures of the new university's merger mandate. The university had been formed through the merger of the University of the North and the Medical University of South Africa (Medunsa) in 2005. Despite the fact that the campuses of the two institutions are some $300 \mathrm{~km}$ apart, a key objective had been to provide the rural Limpopo province with facilities for training in the health sciences: "not only was this aspect of the merger strongly resisted by Medunsa, it also led to a large number of resignations among its highly qualified academic staff". Further complications had stemmed from the joint funding of medical schools by the Department of Higher Education and Training and the provincial departments of health in two different provinces. The overall consequence was the lack of any appropriate institutional mission or shared purpose in the core functions of teaching and learning, research and community engagement (Council on Higher Education 2011a).

Following the HEQC audit, the Minister appointed a task team to investigate and this team reported in July 2011 (South African Government 2011b; Sidimba 2011). The conclusion was that "the merger [...] has not been successful and should be undone. The continuation of the merger will not benefit the current programmes of either campus". In June 2013, the Department of Higher Education and Training reported that the two institutions would be unbundled and Medunsa re-established as an independent university in January 2014 (Phakathi 2013).

In both cases, the unsuccessful mergers lacked a "strong partner", and the merging institutions had been facing considerable challenges prior to the merger process beginning. Neither was able to develop a clear sense of mission or purpose. Campuses of the new institutions are widely dispersed, in some cases hundreds of kilometres apart, with no easy transport networks. Both were designed to cater for students from economically marginalized and low income communities, including a substantial proportion from rural locations, and were expected to engage with these communities in addressing severe and extensive challenges of economic development and the provision of basic facilities.

The third type of outcome of the merger process is where the new universities are seen in their audit reports as still on track to achieving consolidation and integration, but where the process was still incomplete when last reviewed. They do not appear to be facing catastrophic scenarios (such as Walter Sisulu University) or the reversal of the merger (such as the University of Limpopo). However, they did not have the evident advantages of universities such as KwaZulu-Natal and North-West, which entered the merger with the significant assets of a previously advantaged institution. This group comprises the Durban University of Technology, Tshwane University of Technology, the University of South Africa, Cape Peninsula University of Technology and the University of Fort Hare.

When the HEQC audit panel assessed the Durban University of Technology in 2007, it noted that, although established in 2002, it had only been designated as a University of Technology in 2005. At the point of the audit visit, the university had just emerged from a period under the direct control of an Administrator, and the new Vice-Chancellor had only been in office for a few weeks (Council on Higher 
Education 2008b). Chetty has commented that the audit process was itself a significant contributor to advancing a unity of purpose: "when it became known that DUT was going to be audited [...] staff largely set aside their differences, which up until then could be associated with the merger. As expressed by several staff members, the audit had galvanized people into action to portray a united front and not to let the institution down" (Chetty 2010). In one sense, then, while this had been an early, voluntary, merger, the process of establishing the identity and mission of the new university has started later than at other newly-formed institutions.

The HEQC audit report provided guidelines as to how this integration and alignment could be achieved. The university should create "the necessary mechanisms and processes for different layers of the institution to engage with its conceptualisation of 'university of technology', identify a developmental trajectory in relation to the three core functions and draw an implementation plan which establishes clear milestones, time-frames, responsibilities and performance indicators for the achievement of the goal of becoming a university of technology and its implications for the definition of quality". Given its difficult history and conflictual experiences over the preceding 5 years, the university needed "to develop a shared institutional culture which is inclusive, transparent and community-oriented [...] a process of organisation building, led by the new Vice Chancellor, needs to take place in order for staff and students to develop a sense of belonging rooted in the new identity of DUT" (Council on Higher Education 2008b).

The HEQC Audit of the Tshwane University of Technology was also conducted in 2007. This new university had been launched through the merger of three previous technikons: Pretoria Technikon, Technikon Northern Gauteng and North-West Technikon. The audit report expressed concerns "that issues of ideology, race, language and work ethic generally constitute a source of tension among and between staff", and that these issues were not being adequately addressed. There was no apparent sense of a common institutional purpose or new institutional identity (Council on Higher Education 2008a). In 2009, the Minister appointed a commission of inquiry into these ongoing problems (the Sithole Commission). The inquiry concluded that "there is a serious void between Council, the Senate and the executive management on the one hand, and the employees and students on the other. This has resulted in constant accusations and counter-accusations, ultimatums, demands and resulting strife within the University. The structures which were created to serve the interest of the employees and students and to assist governance and management to create an operational environment have become dysfunctional" (South African Government 2010). Following a further report by an Independent Assessor, the university was placed under formal administration until 2012, when a new Council and Vice-Chancellor were appointed.

The post-merger history of the Tshwane University of Technology, then, is similar to that of the Durban University of Technology: a difficult initial period, culminating in government intervention and the appointment of an Administrator, followed by the re-establishment of normal governance and the appointment of a new leadership team. The challenge facing the new leadership is substantial; more 
than 50,000 student registrations and dispersed campuses in four different provinces, including both urban and rural areas.

The University of South Africa (Unisa) was, and is, different from all the other new and already established, universities in South Africa. Traditionally a large and long-established distance provider, it had been adapting to changing circumstances caused by the availability of new technologies and the emerging needs of its students. The merger, which had been hotly contested in a public dispute and court action, was intended to consolidate the existing institution with other elements of distance provision to create a new form of comprehensive university. This posed particular challenges. As the HEQC noted in the report on its 2008 audit, "Unisa's student throughput does not compare well with other open distance learning institutions. This is a source of great concern for the Panel and an area for improvement of which the institution is aware. The Panel is concerned that the powerful social justice drive which defines Unisa's access mandate might not be realised if students cannot progress through their studies, and the institution cannot produce a significant number of graduates to alleviate the country's skills shortage and contribute to social development" (Council on Higher Education 2010c).

The audit panel noted that "the organisational, financial and human resource demands confronting Unisa from 2004 have been daunting". While "the institution has risen to all these challenges with energy and focus", key aspects of the transition process were incomplete: "the tensions of the merger resulted in a deterioration of the relationship between management and academics. While to a large extent, relations between management and academics have been restored, the Panel found significant expressions of dissatisfaction among academic staff". In particular, workloads were too high: "most academic staff members have too many students to support and staff: student ratios in certain courses are far higher than the college average. [...] the very ambitious nature of Unisa's strategic objectives, particularly in the area of research, might be putting an extraordinary load on staff'" (Council on Higher Education 2010c).

As with the University of South Africa, the announcement of the initial merger that would establish the Cape Peninsula University of Technology had resulted in a public political dispute. Although this had been long resolved by the time that the HEQC audit was conducted in 2010 , the new university had faced considerable challenges, as the audit panel noted: "the multi-campus and demographically diverse nature of the University pose challenges in the areas of student accommodation, suitable educational facilities, and teaching and learning approaches to support student success. The provision of an encompassing student experience that involves residential and day students, and that extends from the lecture halls and laboratories to other social spaces at each campus, is a fundamental challenge for the University". Given this, the panel believed that the "development of a new academic identity and its concomitant institutional culture requires further reflection on issues such as student access and success and the necessary elements of an appropriate student experience" (Council on Higher Education 2011c).

The fifth university in this category is the University of Fort Hare. Here, the university's identity had long been established with a proud reputation for 
educating future leaders; this had been the first university that Nelson Mandela had attended. The merger had sought to widen Fort Hare's scope through the incorporation of an urban campus in the coastal town of East London, which had previously been part of Rhodes University. In comparison with the requirements of other merging institutions, Fort Hare's was a small merger mandate. However, and as the HEQC noted in its report of its 2008 audit, merger had been required in addition to ongoing recovery from near-catastrophe: "Fort Hare's evolution in the last 10 years was marked by an institutional crisis which took the University to the brink of collapse. Since 2000 UFH has been involved in a 'turnaround' strategy as a result of which the institution has managed to re-establish governance structures, achieved administrative stability, cleared its massive debt, and galvanised different internal stakeholders into action around a common academic project" (Council on Higher Education 2009b).

The Higher Education Merger Study Group has added a further perspective on the completion of their monitoring of the Fort Hare merger, also in 2008. In the merger, they reported, "even though programmes were complementary, two different cultures were brought together. UFH Alice offered a full spectrum of programmes to mostly residential students; students were often under-prepared and from rural areas. The East London campus had a more diverse student body of mostly non-residential, part-time, mature and working students, studying a smaller range of programmes mostly at evening classes" (Gillard et al. 2012). In the Study Group's view, the full potential of the merger had yet to be realized. For its part, the HEQC audit team saw the key requirement as finding "ways in which it can conceptually and operationally reconcile its rural and urban orientations without undermining the sustainability and development of the Alice campus" (Council on Higher Education 2009b).

The five universities in this third category of new universities have key aspects of their post-merger histories in common. All experienced a complex and ambivalent start to their emergence as a new university, either because of significant prior issues with which they had to contend (Durban University of Technology, University of Fort Hare), or because of high profile political disputes (Cape Peninsula University of Technology, Unisa), or because of internal gridlock during the key, initial years (Tshwane University of Technology). All of them carry major and extensive responsibility for economically marginalized students and their communities, often with a broad geographical spread. In their new form, they depend on breaking down the long established traditions of racial segregation and on building new commitments and identities. While they may have faced imminent institutional collapse (Tshwane University of Technology, Durban University of Technology, University of Fort Hare), they have survived, and recovered from these crisis interludes. All, though, will require more time before they can be said to have achieved full realignment and integration as new universities.

Taken as a whole, then, the HEQC audit reports for nine of the 11 new universities that were created through the implementation of South Africa's National Plan for Higher Education in 2002 have, with varied degrees of success, established 
distinctive identities. In all cases, the post-merger phase of integration and consolidation remains incomplete. In some cases, it is clear that significantly more than a decade will be needed before all the requirements of the merger are fully met.

\subsection{Progress in Post-apartheid Reconstruction}

Some patterns clearly emerge from the HEQC audit reports and the outcomes of institution-specific studies. It is instructive to set these against the perceptions and concerns that were recorded in interviews with managers and university leaders in the first part of 2002 (Hall et al. 2004a).

Firstly, and most obviously, it is clear that the strength and extent of the assets of the partners in the merger have had a significant influence on the outcome. Notably, each in the set of more successful mergers included a "historically advantaged" institution previously of university status. None of the remaining seven new universities had this advantage. This meant that the distribution of assets across the range of mergers varied enormously, from new buildings and facilities and cash reserves to the consequences of sustained under-investment and already-existing deficits. The risks that these circumstances presented had been very evident to those interviewed in 2003, when there had been deep anxiety about the levels of funding provided by government. The consequences of under-funding have been to perpetuate some of the discriminatory differentiation that had been the signature of apartheid; those new universities, whose mission was primarily to provide opportunities for economically marginalized black students, continued to have the least resourcing in capital investment and facilities.

This pattern of asset differentiation across the range of new universities appears to have been a primary condition, which moderated the effects of other outcomes from the merger process. Where a new university such as KwaZulu-Natal or the North-West started off with a comparatively strong asset base it was more able to mitigate other stresses, as the outcomes of the merger unfolded. The circumstances faced by the new Walter Sisulu University, for example, were in stark contrast; given the sustained marginalization of the University of Transkei and the rural technikons that were brought together in the merger, and the extremes of poverty across the Eastern Cape province, the new university did not have any buffer against other issues that emerged.

Secondly, multi-campus mergers were particularly complicated - a distinctive legacy from the apartheid years. Not surprisingly, the decision to reconstruct Higher Education as a unitary system necessitated the rationalization of a complex and dysfunctional dispersal of facilities. Again, this challenge had been fully anticipated by university managers and leaders in 2003 , who understood only too well how difficult it would be to integrate campuses that could be more than $3 \mathrm{~h}$ drive apart.

In some cases, this was less of an issue. The Nelson Mandela Metropolitan University, for example, was forged for the most part out of two immediately 
adjacent campuses (while also incorporating a campus of the previous Vista University). In contrast, the new North-West University had a particular challenge, with each of three campuses more than $200 \mathrm{~km}$ from the other. The large new Tshwane University of Technology was expected to unite six campuses spread across four of the country's nine provinces. And the University of Limpopo's mission was to bring together Medunsa's urban campus in Pretoria with the former University of the North's campus at Turfloop, some $300 \mathrm{~km}$ away (South African Government 2011a). Situations such as these presented significant difficulties in terms of organizational systems, administrative structures, departmental, Faculty and College structures and governance arrangements, particularly at Senate level.

Thirdly, it is clear in retrospect that strong and decisive initial responses to the announcement of merger details tended to have a sustained influence on the postmerger phase of integration. In 2003, some institutions were moving rapidly to set up Merger Committees and appoint Merger Managers, and were using these as a basis to begin practical collaboration with their merger partners. While there had been persistent calls for guidance and resourcing from the Ministry and its embryonic Merger Unit, these institutions had not waited for these calls to be answered. These strong responses appear to have brought sustained benefits, as the HEQC was to note in several of its audit reports; for example, at the new universities of Fort Hare, North-West and Johannesburg.

Conversely, political deadlock at the leadership level tended to be associated with a slow and prolonged start to the merger process, and coincided with a longer than anticipated process of post-merger integration (as reported for example, in the HEQC audits of Unisa and the Cape Peninsula University of Technology). In general terms, a sufficient minimum level of consensus appears necessary to avoid disaster scenarios, presaged in South Africa's regulatory system by Ministerial intervention, the appointment of an Independent Assessor, the suspension of normal governance and the appointment of an Administrator (all in terms of the Higher Education Act). Both the Durban University of Technology and the Tshwane University of Technology went to the brink of collapse but were able to recover. In the case of the University of Limpopo, no consensus was achieved between the merger partners and their leadership, and this merger has consequently failed.

Fourthly, compliance with labour legislation has often been particularly difficult. Again, this was widely anticipated in 2002/2003, both by government (in its amendment of the Higher Education Act) and by merging institutions. Apartheid segregation had created widely differing conditions of employment and consequent expectations. Technikons and universities had differing professional requirements of their staff and qualification structures. Behavioural differences tended to become attenuated, from language choice (South Africa has 11 official languages) and dress code, to parking arrangements. Both the HEQC audit reports and the Higher Education Mergers Study Group overview stress the ongoing need to achieve the harmonization of conditions of employment in the new universities. Where circumstances had deteriorated to the point where the Minister was obliged to appoint 
an Administrator, crippling industrial disputes were invariably a significant factor in institutional breakdown.

Fifthly, educational mission and the alignment of academic programmes and qualifications remains, in all cases, a substantial issue. There are two, interlocked, issues here: the interpretation of the threefold differentiation between traditional, comprehensive and technical universities introduced as part of the merger policy, and the challenge of realigning all the academic programmes and qualifications offered across a single new university. These challenges were fully anticipated in 2002/2003. Those who were interviewed were concerned about the capacity to meet merger requirements at the same time that the Ministry was requiring academic programme and qualification alignment and regional collaboration outside, and in parallel with, the merger processes.

Neither of the more successful of the new "traditional universities" (KwaZuluNatal and North-West) had achieved sufficient programme integration at the point at which they were reviewed by either the Higher Education Mergers Study Unit or the HEQC (in 2007 and 2009 respectively). For the "comprehensive universities" the problem was compounded by the need to define this new category. Professor Angina Parekh, a deputy vice-chancellor at the University of Johannesburg and previously Head of the Department of Education's Merger Unit, expressed this problem candidly: "having done mergers, there now isn't a very clear idea of what the institutions are and how they should deliver on their mandate. It has been left to universities to decide [...]" (Mgqibela 2008).

In addition to these five sets of issues that had been presaged in 2002 and 2003, as preparations for the mergers were in full swing, there were additional dimensions that may not have been sufficiently appreciated at the planning stage but which, in retrospect, have been significant: institutional culture, the socio-economic context in which specific universities must operate, and the challenge of bringing students along with the objectives of the merger process.

Institutional culture can be understood as the combination of traditions, organizational structures and group and individual behaviour that, together, come to define a university's identity. All the new universities were still facing substantial challenges in this area, when visited by HEQC audit teams or by the Higher Education Mergers Study Group, and this was often expressed by staff referring back to institutional identities prior to the merger process. Where institutions got into particular difficulties, requiring the appointment of an Independent Assessor and Administrator, reports invariably point to a failure to establish a distinctive sense of identity or purpose (see Arnolds et al. 2013).

As has been noted, South Africa is characterized by extreme income inequality. Since the first universal elections of 1994, this income inequality has persisted, and has been complicated by increased unemployment. At the same time, though, the system-wide merger proposal adopted by government was cast as a national project of reconstruction, seeking a unitary system of higher education comparable with contemporary international standards. As the Higher Education Mergers Study Group noted, this has encouraged "mission drift" in which prestige is granted to research leadership and academic qualifications rather than in terms of responding 
to the needs of specific student populations. This policy framework may have resulted in insufficient recognition (and therefore inappropriate resourcing and expectations) of those new universities that would carry the primary burdens of sustained and extensive inequality: universities serving large rural areas, sometimes with urban campuses as well (Tshwane University of Technology, University of Fort Hare, University of Limpopo, Walter Sisulu University of Science and Technology), and universities serving low income communities in South Africa's three sprawling urban metropolitan areas (Durban University of Technology, Cape Peninsula University of Technology, University of Johannesburg).

Given the burden that all new universities have faced over the decade since mergers were announced, those that were exempted from merger have had a corresponding advantage. Some of these "old" universities were already facing significant challenges in serving marginalized students and communities (University of the Western Cape, University of Zululand, University of Venda). Others were already an elite group, and were the preference of the new black middle class (University of Cape Town, University of Pretoria, Rhodes University, University of Stellenbosch, University of the Witwatersrand). Given this, one consequence of the merger process, at the system level, may have been to further exacerbate inequality by increasing the premium value of admission to a local "Ivy League".

Not surprisingly, students have strong views on this issue, given their primary interest in educational outcomes. Those who are educationally qualified have demanded - and received - admission to the small set of elite universities, irrespective of their race. Those who have not had adequate qualifications for admissions to highly selective institutions - overwhelmingly those from low income families whose immediate forbearers had been the primary victims of apartheid - readily appreciated that the universities that they could attend had far fewer facilities, and that the educational qualifications that they would receive would have significantly less value in the labour market. In consequence, it is not surprising that they have tended to be angry and militant, and have often formed alliances with disaffected employees. At both the Tshwane University of Technology and the Walter Sisulu University of Science and Technology, student alliances with trade unions directly led to the suspension of autonomous governance and the appointment of an Administrator.

In general terms, student distance from the merger process was captured in debates at the South African Students Congress (SASCO) conference in 2009. The new universities created by the mergers were seen as having failed the requirements of the labour market. Patterns of graduate unemployment showed that previous patterns of discrimination and disadvantage had continued despite the merger process, and employers remained prejudiced against black graduates from disadvantaged backgrounds. Overall, SASCO saw the impact and outcomes of the mergers as unclear and called for a Commission of Inquiry to review the process and its consequences (SASCO 2009). 


\subsection{Conclusions}

How successful, then, have Higher Education mergers been in South Africa? In drawing some conclusions from both the perspective of systemic national-level and institutional structure and of students, the pervasive effects of inequality permeate all aspects of both the mergers and the subsequent fortunes of both the new universities and those that were exempt from merger (Hall 2012a, b).

South Africa has long had, and continues to have, one of the highest levels of income inequality in the world (Seekings and Nattrass 2005; Statistics South Africa 2008). As in other countries, variations in household income have a direct affect on educational attainment. In 2007, just under one million young South Africans were eligible to enter the final examinations for compulsory education (the Matriculation Examination), $83 \%$ of whom were African and $7 \%$ were White. $35 \%$ of the African candidates and $64 \%$ of the White candidates wrote the examinations and passed. Of these, $34 \%$ of the White candidates achieved an endorsement: the minimum grades in specified combinations of subjects to be eligible to apply for higher education. Only $6 \%$ of African candidates achieved an endorsement. In South Africa, an A-aggregate is required for the most selective university programmes. One in 11 White candidates achieved an A-aggregate. This was matched by just one in 640 African candidates. As many commentators have noted, despite government focus on resourcing, South Africa's schools chronically underperform compared to similar emerging economies (Hall 2012a, b).

This pattern of inequality results in a distinctive "articulation gap" - the signature of South African schooling, and of subsequent opportunities after compulsory education (Council on Higher Education 2013a). In consequence, universities face widely different challenges. The level of educational attainment, material resources and expectations of a student enrolling at the University of Cape Town are very different from those of a student entering the Tshwane University of Technology. Any evaluation of the comparative success of universities in South Africa has to take account of the continuing, material effects of pronounced inequality.

But, significant as it is, continuing inequality does not fully account for graduate outcomes across South Africa's Higher Education system. This has been confirmed by the first system-wide study of student access to all South Africa's public universities and students' subsequent fortunes and levels of success. The core of this analysis is the student cohort that entered Higher Education in 2006, the first academic year following the completion of the merger process. This has shown that, while the effects of inequality are evident, underperformance by students from privileged backgrounds entering the most selective universities is also prevalent: "It is clear that systemic problems affect the whole school system, the functional and well-resourced schools, as well as the dysfunctional and poorly-resourced ones". No socioeconomic or racially-defined group is performing well, and more than a third of the best performing group - white students mainly studying at wellresourced, traditional universities - fail to graduate within 5 years (Council on Higher Education 2013a). 
Given these continuing challenges, then, has the reorganization of South Africa's higher education system broken the "structural embrace" of apartheid architecture, rooted in colonial education systems and formalized under the National Party governments of 1948-1990?

In one sense, this has evidently been the case, as the universities that the newly elected government inherited in 1994 were impossibly compromised. This was apparent through successive studies by the Council on Higher Education and in the recommendations brought together in the National Plan for Higher Education. Although there had been both the relaxation of regulations, and reforms, in the 1980s, it must be recalled that everything about South Africa's universities had been shaped by the practices and objectives of racial segregation. As Hendrik Verwoerd - then Minister of Native Affairs, later Prime Minister - had put it in 1953: "there is no place for [the Bantu] in the European community above the level of certain forms of labour [...] What is the use of teaching the Bantu child mathematics when it cannot use it in practice?" (Clark and Worger 2011).

Indeed, one criticism could be that the merger project did not go far enough. The National Commission on Higher Education, which had reported in 1996, had seen the whole system as dysfunctional; however, the proposals adopted by the government in 2002 left eight existing universities unchanged. The overview of the HEQC audit reports in this chapter suggests that a successful merger outcome has, a decade later, been associated with there being a strong partner in the process; in other words, a university that had been differentially favoured through the apartheid years. What would have happened if each of the Universities of Cape Town, Free State, Pretoria, Stellenbosch and Witwatersrand had been required to merge with a partner that had been reserved for black South Africans in the apartheid schema?

The decision to exclude a significant number of existing institutions has clearly diminished the overall effect of the merger process. This can be expressed through the proxy of undergraduate headcount enrolments in 2011 - the fifth year following the admission of the 2006 cohort, which has been analysed by the Council on Higher Education (Council on Higher Education 2013a). Headcount enrolments for all universities are given in Table 8.1. Excluding Unisa's distance education enrolments, only $51 \%$ of these students were registered in merged institutions. Within this group of new universities, $25 \%$ of total headcount enrolments were registered in the four "strong" mergers. A further $19 \%$ were enrolled in the four "unresolved" mergers and $7 \%$ were in the two failed mergers. In practice, this means that only a quarter of all 2011 undergraduate students were in truly "new" universities. This is not the extensive restructuring that had been recommended by the National Commission on Higher Education in 2001.

A second way of evaluating the overall merger process at the system level is in terms of national workforce planning; the provision of sufficient, and appropriately qualified, graduates for South Africa's present and future needs.

On the one hand, the overall size of the Higher Education system has continued to grow. Overall enrolment has increased by over $80 \%$ since 1994, to a total enrolment of over 900,000 . This expansion has contributed to redressing racial inequities, with African enrolments reaching $79 \%$ of total enrolments by 2010 , and 
the number of African first-degree graduates growing by $50 \%$ between 1995 and 2010 (Council on Higher Education 2013a). Whether or not this gross expansion would have happened without mergers is of course unknowable; clearly, though, mergers have not impeded overall expansion. In 2012, the government published a new National Development Plan. This has called for this expansion to continue, and to result in ten million graduates in 2030 (one in every six people), in contrast with 2001, when there were 2.6 graduates in the South African populations as a whole, one in every 17 people (Government of South Africa 2012).

Despite this overall growth, the National Development Plan is explicit in its criticisms of the suitability of the country's graduates for national workforce requirements: "the data on the quality of university education is disturbing. South African universities are mid-level performers in terms of knowledge production, with low participation, high attrition rates and insufficient capacity to produce the required levels of skills. They are still characterised by historical inequities and distortions. The university sector is under considerable strain. Enrolments have almost doubled in 18 years, yet the funding has not kept up, resulting in slow growth in the number of university lecturers, inadequate student accommodation, creaking university infrastructure and equipment shortages. The number of institutions that have recently been put under administration is an indication of the leadership and governance challenges" (South African Government 2012).

These deficits have been examined in detail by the Council on Higher Education's Task Team on undergraduate curricula structure (Council on Higher Education 2013a). When considered in terms of participation rates (using the standard Gross Enrolment Ratio), the targets set in the 2001 National Plan for Higher Education have been met, increasing from $15 \%$ in 2000 to $18 \%$ in 2010. However, pronounced racial inequalities persist. While white participation is comparable with developed country levels, the participation rate for black students is persistently low. The task team concluded: "the output of higher education is not meeting the country's needs [...] the system has low internal efficiency in utilising human and material resources (and consequently does not provide a sound basis for growth), and [...] the scale of the failure and dropout occurring within a small and selected student body points to substantial systemic problems that require systemic responses. It can be said that, in relation to its educational role, higher education in South Africa is a 'low-participation, high-attrition system' [...] that has not yet come to terms with its developing-country environment" (Council on Higher Education 2013a).

At the overall system level, then, outcomes of mergers have been mixed. What is still unclear is what will emerge from the five remaining, new universities that have certainly not failed, but which were still implementing key aspects of their mergers at the time of their HEQC audit reports. Leaving aside the special case of the Unisa, these are the Durban University of Technology, the Tshwane University of Technology, the Cape Peninsula University of Technology and the University of Fort Hare. Two are metropolitan, and two span the complex spread of urban and rural catchments. Three are universities of technology. Given their particular missions, 
they can be seen as bellwethers for the future success of the education objectives set out in the 2012 National Development Plan.

The comparative success of individual institutions, as suggested in their HEQC audit reports, has already been described in terms of the availability of assets and financing, the challenges of multi-campus mergers, the alignment of academic programmes and qualifications, and institutional culture. These factors have evidently shaped patterns of success over the years following merger. In addition, a key aspect of the 2002 merger plan was a national mix of three kinds of institution: traditional universities, comprehensive universities, and universities of technology. To what extent has this trio of institutional types been consolidated as definitive of South African Higher Education? Again, the 2011 headcount enrolments shown in Table 8.1 can be as a proxy for the mix of post-merger institutional types. Turning now to this institutional level, which sets of conditions that were discernable at the beginning of the merger process in 2002 appear to have driven degrees of success over the following decade?

Firstly, and significantly, a third of all registered undergraduate students are with Unisa. For South Africa's very large distance provider, the breaking revolution in digitally-enabled, blended and on-line learning will have more significance than the new institutional models created by the 2002 merger plan. This will be a significant challenge, as is evident from the Council on Higher Education's analysis of the fortunes of the 2006 student cohort. For Unisa, the rates of attrition within 4 years of the expected completion time were $67 \%$ for 3-year degrees (in other words, allowing 7 years for completion), $67 \%$ for 4-year degrees (allowing 8 years for completion), and $86 \%$ for 3-year diplomas (allowing 7 years for completion) (Council on Higher Education 2013a). Given this, there is an evident category error in regarding Unisa as a comprehensive university of similar type to, for example, the University of Johannesburg or the University of Venda. Distance provision in South Africa needs to be considered as a category of its own. This has been recognized in the 2012 National Development Plan. As a priority for investment through to 2030, the NPD notes the need to expand, and invest in distance education: "the advances in ICT can help overcome the infrastructure limits to further expansion of higher education. Upfront investment is needed in technology, curriculum design, quality assurance and monitoring" (South African Government 2012).

Secondly, when Unisa registrations were excluded, the distribution of 2011 headcount enrolments were $53 \%$ in traditional universities, $21 \%$ in comprehensive universities and $26 \%$ in universities of technology. When the pre-reform distribution of assets and institutional capabilities is also taken into account, it is clear that the traditional university remains the overwhelmingly dominant form of higher education in South Africa. This is mirrored in patterns of state expenditure. Government accounts confirm that ZAR2.8bn $(\$ 346 \mathrm{~m})$ was spent on mergers over five successive funding years, beginning in 2004. This money was retained in the overall Higher Education budget, while being reallocated to fund infrastructure and efficiency grants from 2008 onwards (with an allocation of ZAR1.1bn in 
2008/9, growing to ZAR1.6bn in 2011/12 - an increase from $\$ 134 \mathrm{~m}$ to $\$ 186 \mathrm{~m}$ ). ${ }^{2}$ Since this funding was available to all universities, this allocation policy has had the effect of further diminishing financial support available for the experiment with comprehensive universities and universities of technology, and of buttressing the comparative strength of traditional universities. Indeed, the primary importance of traditional universities is endorsed and emphasized by the National Planning Commission in its proposals that look forward to 2030 (Government of South Africa 2013a).

Thirdly, as the National Development Plan makes clear, the present and future needs of universities require far greater attention to the articulation between the school system, further education and vocational provision. In considering the success of the 2002 merger plan, this puts a spotlight on universities of technology and comprehensive universities as institutional types. How effective have they been in ensuring an effective spectrum of provision across all aspects of post-compulsory provision?

In total, the 2002 policy established six technical universities, three through mergers, and from a set of ten preceding technikons. Excluding Unisa, five comprehensive universities were established at the same time, three from mergers between previous technikons and traditional universities, and two by re-designating earlier, traditional universities that had, during the apartheid years, been set up for ethnically defined black "homelands" (Table 8.1). The mission intended for these 11 institutions was to span the distinction between vocational and academic qualifications, by means of a range of diplomas and degrees. It had been clear from the interviews carried out in early 2003 that there was little clarity as to how these broad intentions should, or could, be implemented at the level of the individual institution. The subsequent HEQC audit reports show that this lack of clarity often persisted after the mergers had been completed.

The mix of qualifications attained across the Higher Education system as a whole is reflected in the relative proportions of 3 year degrees and vocational diplomas. In 2001, when the merger process was launched, the ratio of degrees to diplomas was 55:45. By 2011 the overall number of graduates with these two types of qualification had increased by $71 \%$. However the ratio of degrees to diplomas was still $55: 45 .^{3}$ This suggests that, contrary to intention, the merger process has had at best no effect on rebalancing the overall proportions of vocational and academic qualifications that have been attained.

Overall, there is no evidence that the comprehensive university, as a new institutional type, has emerged as a strong identity. Given this, it is telling that the 2012 National Development Plan all but ignores the merger process of a decade earlier and, in addressing the challenge of articulation between vocational and academic provision, simply restates the problem that the National Commission on

\footnotetext{
${ }^{2}$ Higher Education and Training, University State Budgets. Jane Hendry, personal communication, 17 October 2013

${ }^{3}$ National HEMIS data base; Jane Hendry, personal communication, 17 October 2013.
} 
Higher Education had addressed in 2001: "building an expanded, differentiated university system requires that other post-school institutions function optimally. If the college sector functions optimally, the pressure on universities to offer lower level diplomas and certificates will be reduced. This will allow universities to focus on their niche" (South African Government 2012).

Fourthly, this highlights the particular consequences of the failure to focus on curriculum reform as a central pillar of the 2002 merger plan. Interviews in 2003 showed a near-universal concern about academic programme reform, and articulation and subsequent HEQC audit reports have, in several cases, highlighted the problems that have followed as a consequence. At one extreme is the University of Limpopo, where the failure to align the educational missions of the two institutions entering the merger has been formally credited as the reason for the failure of the merger process. More prevalently, universities of technology and comprehensive universities have found it difficult to integrate very different kinds of curriculum structure.

The most recent Council on Higher Education's investigation hints that the considerable institutional effort that has been put into tackling this problem may have yielded some positive results. The Council's report notes that, contrary to a general trend of deteriorating quality of student results, there have been improvements in achievement by students studying for diplomas: "in some cases, the institutional mergers coming into effect at that time may have focused attention on educational management, but it is not clear what short-term improvements they may have brought about in teaching and learning" (Council on Higher Education 2013a). However, the overwhelming conclusion of the task team is that South Africa's undergraduate curriculum structure is beyond repair, and needs comprehensive revision. As with the work of the National Planning Commission, the task team barely mentions the 2002 merger plan, and rather refers back to the 1997 White Paper as its reference point for essential changes to the higher education system.

Overall then, it seems that the implementation of the 2002 merger plan has had little sustained effect on institutional forms and structures. While, within institutions, considerable work has been put into interpreting what technical and comprehensive universities should be in distinction to traditional universities, institution structures long-established before the adoption of the merger plan have remained dominant. The most recent policy documents, including the country's formally adopted National Development Plan that is intended to shape government policy over the next two decades, all but ignore the merger process and revert to the earlier challenges of recovery from the apartheid years.

From the student perspective, to what extent has the merger process contributed to addressing access and subsequent levels of success - who gets in, and how do they get on? More specifically is there any evidence, from the experience of the first post-merger student cohort that enrolled in 2006, that the mergers have made a difference?

The cohort analysis commissioned by the Council on Higher Education shows a pattern of high overall undergraduate attrition. Five years after entering, only $35 \%$ 
of the 2006 cohort had graduated (45\% when UNISA students are set to one side). For traditional 3 and 4 year undergraduate degree programmes only $52 \%$ of the 2006 entering cohort had graduated after 5 years; the completion rate for diplomas after 5 years was only $42 \%$; particularly significant for the missions of the new comprehensive universities and universities of technology.

Equity, the representivity of the population as a whole in the profile of graduates, is also an important indicator of the extent to which universities are meeting the legitimate expectations of their students. While remaining low, 5-year completion rates for African students increased significantly when the fortunes of the 2000 and 2006 cohorts are compared (to the extent that data are available). In addition, the average gap between the African and white 5-year completion rates narrowed appreciably from the 2000 to the 2006 cohort, although this was in part due to a deterioration in the white completion rate. However, these changes pre-date the implementation of mergers and the overall situation is still that only $5 \%$ of young black South Africans are succeeding in higher education (Council on Higher Education 2013a).

As far as students are concerned, then, the effects of the merger process seem to be at best neutral. Have mergers damaged student prospects? Has the amount of scare institutional resources diverted to merger processes, the problems of "pipeline" students identified back in 2002 and the lack of a focus on curriculum reform detracted from improving teaching and providing student support? Here, a rough proxy is the proportion of students enrolled in universities where difficulties have been sufficient to require direct ministerial interventions in terms of the Higher Education Act. This has happened in four cases, with headcount enrolments in 2011 of just under 122,000 students, or $20 \%$ of the country's total undergraduate student enrolment, excluding Unisa students. Disruptions of this magnitude would have a considerable impact on any country's Higher Education system, and all the more so through a period of national reconstruction following sustained and institutionalized discrimination.

Overall - and bringing together effects at the levels of the national system, individual universities and student expectations - South Africa's Higher Education mergers have probably been irrelevant to the long-term process of recovery from the apartheid years. Trends evident prior to the implementation of the 2002 merger plan have continued despite the merger process. While it has been important to dismantle to visible manifestations of apartheid, such as segregated campuses, the correlation between wide differences in access to educational facilities and race and economic circumstances are still only too evident.

In January 2005, both the Walter Sisulu University of Technology and Science and the Nelson Mandela Metropolitan University were inaugurated, named for the two iconic leaders of opposition to apartheid. In January 2013, students enrolling at these universities had very different backgrounds and experiences, and will have widely divergent prospects. In this, the core objective of reform of Higher Education in South Africa, as expressed in the 1997 White Paper, remains unrealized: 
the higher education system must be planned, governed and funded as a single national coordinated system. This will enable us to overcome the fragmentation, inequality and inefficiency which are the legacy of the past, and create a learning society which releases the creative and intellectual energies of all our people towards meeting the goals of reconstruction and development (South African Government 1997a).

Acknowledgments I am grateful to Ashley Symes and Thierry Luescher for making this study possible through our baseline research during the early stages of the merger process. Brenda Cooper, Jane Hendry, Erica Gillard, Ian Scott and the editors of this volume have commented on earlier drafts of this chapter, for which I am also most grateful.

Open Access This chapter is distributed under the terms of the Creative Commons Attribution Noncommercial License, which permits any noncommercial use, distribution, and reproduction in any medium, provided the original author(s) and source are credited.

\section{References}

Arnolds, C., Stofile, R., \& Lillah, R. (2013). Assessing the outcomes of the higher education mergers in South Africa: Implications for strategic management. Acta Commercii, 13(1), 1-11. http://dx.doi.org/10.4102/ac.v 13i1.175

Brooks, S. (2011, January 24). A crisis of credibility. Natal Witness. http://www.witness.co.za/ index.php?showcontent\&global\%5b_id\%5d=54345[25/01/2011

Chetty, G. (2010). The transformation of the South African higher education sector through mergers - The case study of the Durban University of Technology. Doctor of technology, Durban University of Technology: Faculty of Management Sciences Human Resources Management.

Clark, N., \& Worger, W. (2011). South Africa - The rise and fall of apartheid (Seminar studies in history). London: Longman.

Council on Higher Education. (2000). Towards a new higher education landscape: Meeting the equity, quality and social development imperatives of South Africa in the 21st Century. Pretoria: Council on Higher Education.

Council on Higher Education. (2002). Policy report: Promoting good governance in South African higher education. Pretoria: Council on Higher Education.

Council on Higher Education. (2008a). Audit report on the Tshwane University of Technology: Executive summary. Audit Report 18. Pretoria: Council on Higher Education. http://www. che.ac.za/sites/default/files/institutional_audits/institutional_audits_2007_tut_executive_ summary.pdf

Council on Higher Education. (2008b). Audit report on the Durban University of Technology: Executive summary. [Online] Audit Report 21.

Council on Higher Education. (2009a). Audit report on the Nelson Mandela Metropolitan University: Executive summary. [Online] Audit Report 25. Available at: http://www.che.ac.za/ sites/default/files/institutional_audits/institutional_audits_2008_nmmu_executive_summary. pdf

Council on Higher Education. (2009b). Audit report on University of Fort Hare: Executive summary. [Online] Audit Report 23. Available at: http://www.che.ac.za/sites/default/files/ institutional_audits/institutional_audits_2008_ufh_executive_summary.pdf

Council on Higher Education. (2010a). Audit report on the University of Johannesburg: Executive summary. [Online] Audit Report 28. Available at: http://www.che.ac.za/sites/default/files/ institutional_audits/institutional_audits_2009_uj_executive_summary.pdf 
Council on Higher Education. (2010b). Audit report on North-West University: Executive summary. [Online] Audit Report 27. Available at: http://www.che.ac.za/sites/default/files/institu tional_audits/institutional_audits_2009_north_west_university_executive_summary.pdf

Council on Higher Education. (2010c). Audit report on the University of South Africa: Executive summary. [Online] Audit Report 24.. Available at: http://www.che.ac.za/sites/default/files/ institutional_audits/institutional_audits_2008_unisa_executive_summary.pdf

Council on Higher Education. (2011a). Audit report on the University of Limpopo: Executive summary. [Online] Audit Report 31. Available at: http://www.che.ac.za/sites/default/files/ institutional_audits/institutional_audits_2010_lp_executive_summary.pdf

Council on Higher Education. (2011b). Audit report on Walter Sisulu University: Executive summary. [Online] Audit Report 33. Available at: http://www.che.ac.za/sites/default/files/ institutional_audits/institutional_audits_2011_wsu_executive_summary.pdf

Council on Higher Education. (2011c). Audit report on the Cape Peninsula University of Technology: Executive summary. [Online] Audit Report 32. Available at: http://www.che.ac.za/ sites/default/files/institutional_audits/institutional_audits_2010_cput_executive_summary.pdf

Council on Higher Education. (2013a). A proposal for undergraduate curriculum reform in South Africa: The case for a flexible curriculum structure. Report of the task team on undergraduate curriculum structure. Pretoria. http://www.che.ac.za/sites/default/files/publica tions/Full_Report.pdf

Council on Higher Education. (2013b). Summary of audit reports. [Online] Available at: http:// www.che.ac.za/focus_areas/auditing_of_institutions/summary_of_audit_reports. Accessed 25 Aug 2013.

Eastman, J., \& Lang, D. (2001). Mergers in higher education: Lessons from theory and experience. Toronto: University of Toronto Press.

Gillard, E., Saunders, S., Terblanche, J., \& Sukel, M. (2012). A review of four case studies in restructuring the South African higher education system. [Online] Available at: http://ahero. uwc.ac.za/index.php? module $=$ cshe\&action $=$ viewtitle $\&$ id $=$ cshe_ 842

Goedegebuure, L. (1992). Mergers in higher education. Utrecht: Centre for Higher Education Policy Studies.

Goldman, G. (2012). Exploring academics' experiences of a merger in higher education: The reflective experience of mergers (REM)-framework. African Journal of Business Management, 6(14), 4862-4879.

Government of South Africa. (2013a). Publication of lists of species that are threatened or protected, activities that are prohibited and exemption from restriction. Notice 389 of 2013. Government Gazette, 16 April 2013, No. 36375. (10505), pp. 104-219.

Hall, M. (2012a). Inequality and higher education: Marketplace or social justice? London: Leadership Foundation for Higher Education.

Hall, M. (2012b). Inequality, and the public good and private benefits of higher education. In B. Leibowitz (Ed.), Higher education for the public good; Views from the south. Stoke-onTrent: Trentham Books.

Hall, M., \& Symes, A. (2003). Co-operative governance or conditional autonomy? Principles for governance of South African higher education, 2, 5-29.

Hall, M., \& Symes, A. (2005). South African higher education in the first decade of democracy: From co-operative governance to conditional autonomy. Studies in Higher Education, 30(2), 199-212.

Hall, M., Symes, A., \& Luescher, T. (2002). Governance in South African higher education. Research report prepared for the Council on Higher Education. Pretoria: Council on Higher Education.

Hall, M., Symes, A., \& Luescher, T. (2004a). The governance of merger in South African higher education. Pretoria: Council on Higher Education.

Hall, M., Symes, A., \& Luescher, T. (2004b). The culture of governance in South African public higher education. Journal of Higher Education Policy and Management, 26(1), 91-107. 
McKune, C. (2009). Management shows contempt for academic freedom at UKZN. South African Journal of Science, 105, 5-6.

Mgqibela, L. (2008). Comprehensive university reality "fraught and complicated". University World News, (1). http://www.universityworldnews.com/article.php?story $=20080129095708408$

National Commission on Higher Education. (1996). A framework for transformation. Pretoria: HSRC Publications.

National Working Group. (2001). 23549 The restructuring of the higher education system in South Africa: Report of the national working group to the Minister of Education. Pretoria: Government Gazette Government Printers.

NEPI. (1993). National education policy investigation: The framework report and final report summaries. Cape Town: Oxford University Press.

Phakathi, B. (2013, June 19). Unbundling of University of Limpopo nearly finalized. Business Day. http://www.bdlive.co.za/national/education/2013/06/19/unbundling-of-university-of-lim popo-nearly-finalised

SASCO. (2009). Beyond the big bang mergers: A critical review of the higher education mergers in South Africa. SASCO 16th National Congress discussion document: Education transformation. http://www.sasco.org.za/docs/congress/16_congress/he_mergers.pdf

Seekings, J., \& Nattrass, N. (2005). Class, race and inequality in South Africa. New Haven: Yale University Press.

Sidimba, L. (2011, July 24). Don't close under-fire Medunsa - report. News24. http://www. news24.com/printArticle.aspx?iframe \&aid $=9 f 4 d b d a 3-c 871-433 e-a e 30-61123 a 7 f 81 d 5 \&$ cid $=1057$

South African Government. (1997a, August 15). A programme for the transformation of higher education. Education White Paper 3. Government Gazette.

South African Government. (1997b, December 19). Higher Education Act No. 101 of 1997. Government Gazette. Amended in 1999, 2000, 2001 and 2002.

South African Government. (2001). National plan for higher education. Pretoria: Ministry of Education.

South African Government. (2002a, December 19). Higher Education Amendment Act No. 63 of 2002. Government Gazette.

South African Government. (2002b, June 21). Transformation and restructuring: A new institutional landscape for higher education. Government Gazette.

South African Government. (2010, November 22). Investigation into the Tshwane University of Technology. Government Gazette.

South African Government. (2011a, July 8). Report of the task team into the impact of the merger between Medunsa and the University of the North to form the University of Limpopo and training of the education and health professionals, appointed by the Minister of Higher Education and Training. Government Gazette.

South African Government. (2011b). Statement by higher education and training minister Dr Blade Nzimande on the appointment of an administrator for Tshwane University of Technology. [Online] Available at: http://www.info.gov.za/speech/DynamicAction?pageid=461\& sid $=20757 \&$ tid $=39623$

South African Government. (2011c, September 28). Report of the independent assessor into the affairs of the Walter Sisulu University, appointed by the Minister of Higher Education and Training. Government Gazette.

South African Government. (2012). National development plan: Our future. Make it work. Pretoria: National Planning Commission. http://www.info.gov.za/view/DownloadFileAction? $\mathrm{id}=172306$

Statistics South Africa. (2008). Income and expenditure of households 2005/2006: Analysis of results. Pretoria: Statistics South Africa.

Van Straaten Theron, A., \& Dodd, N. (2011). Organisational commitment in a post-merger situation. South African Journal of Economic and Management Studies, 14(3), 333-345. 